\title{
Ghrelin Improves the Fine Structure of Atrial Natriuretic Factor (ANF) Granules and Intercalated Disc Junctions in Experimentally-Induced Myocardial Infarction in Rats
}

\author{
La Grelina Mejora las Estructuras Finas de los Gránulos de Factor Natriurético Atrial (ANF) y \\ las Uniones Intercaladas de Disco en el Infarto de Miocardio Inducido Experimentalmente en Ratas
}

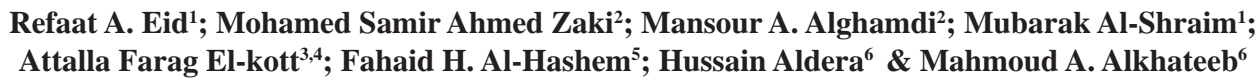

EID, R. A.; ZAKI, M. S. A.; ALGHAMDI, M. A.; AL-SHRAIM, M.; EL-KOTT, A. F.; AL-HASHEM, F. H.; ALDERA, H. \& ALKHATEEB, M. A. Ghrelin improves the fine structure of atrial natriuretic factor (ANF) granules and intercalated disc junctions in experimentally-induced myocardial infarction in rats. Int. J. Morphol., 36(3):1031-1042, 2018.

SUMMARY: Ghrelin is a novel growth hormone-releasing peptide administered to treat myocardial infarction (MI). However, the underlying mechanism of its protective effects against MI remains unclear. A total of sixty healthy Sprague Dawley male rats were included. The first one is the sham-operated control group were the rats that underwent the same surgical used to induce MI but without tying the left anterior descending coronary artery (LAD) and received normal saline $(0.5 \mathrm{ml})$ as vehicle; the second MI model group were rats with LAD ligation and received normal saline $(0.5 \mathrm{ml})$ and the third one is MI+ghrelin group were rats that were exposed to surgery to induce MI but received ghrelin $(100 \mu / \mathrm{kg}$, orally, 2x/day). At the end of the experiment after 21 days post-MI, rats were sacrificed and processed for ultrastructural demonstration. Our experiment showed that ghrelin inhibited cardiomyocyte apoptosis. Concomitant administration of ghrelin with MI treated rats of this study appeared to show a considerable protection of the atrial tissues. This study revealed that the sarcoplasm was occupied by normal myofibrils with clear striations and others appeared with minor disruption. Normal distribution of atrionatriuretic factor (ANF) granules and well preserved mitochondrial integrity (preserved cristae, normal size and shape), nucleus chromatin arrangement and striated pattern of clear bands ( $\mathrm{Z}$ and $\mathrm{H}$ ) compared to the MI group. Intact intercalated disc with clear identification of fully formed fascia adherence and desmosomes with a reconstruction of gap junction (nexus) was also noticed. Atrial myocytes after myocardial infarction is often associated with subsequent heart failure, which could lead to a fatal outcome. In a rat model of experimental myocardial infarction, peripheral ghrelin administration attenuated myocyte dysfunction, well-preserved desmosome, adherent and gap junction of the intercalated disc and normally distributed ANF granules.

KEY WORDS: Ghrelin; Myocardial infarction; Atrial natriuretic factor; Intercalated disc junctions; Rats.

\section{INTRODUCTION}

The search for effective methods of myocardial cytoprotection against MI is the most desirable and relevant issue in modern cardiology and especially cardiac surgery. The protection of myocardial muscle from ischemia-induced left ventricular dysfunction during coronary artery bypass grafting, valve surgery, or heart transplantation is an essential matter for further success of the cardiac procedure. With age, this protection is reduced by altered mitochondrial metabolism. In the aged heart, the mitochondria appeared defective that lead to enhanced oxidative injury and the activation of signaling for cell death (Lesnefsky et al., 2016).
Myocardial infarction is the leading cause of death in developed nations. This event results from the abrupt reduction of coronary flow in a segment of the myocardium. Consequently, severe cellular changes ensue and inevitably end in cell death and necrosis (Hearse, 1998). The damage that occurs in the myocardium due to ischemia is mainly due to an increase in the levels of reactive oxygen species (ROS) (Ryter et al., 2007). ROS can be produced in the cell by various enzymes including NADPH oxidase (NOX) and nitric oxide synthase (NOS) owing to a lack of tetrahydrobiopterin cofactor (BH4) (Finkel, 1999; Sorescu

\footnotetext{
${ }^{1}$ Department of Pathology, College of Medicine, King Khalid University, Abha, Saudi Arabia.

${ }^{2}$ Department of Anatomy, College of Medicine, King Khalid University, P.O. 641, Abha, 61421, Saudi Arabia.

${ }^{3}$ Department of Biology, College of Science, King Khalid University, P.O. 641, Abha, 61421, Saudi Arabia.

${ }^{4}$ Department of Zoology, Faculty of Science, Damanhour University, Damanhour, Egypt.

${ }^{5}$ Department of Physiology, College of Medicine, King Khalid University, P.O. 641, Abha, 61421, Saudi Arabia.

${ }^{6}$ Department of basic medical Sciences /College of Medicine/ King Saud bin Abdulaziz University for Health Sciences, Saudi Arabia.
} 
EID, R. A.; ZAKI, M. S. A.; ALGHAMDI, M. A.; AL-SHRAIM, M.; EL-KOTT, A. F.; AL-HASHEM, F. H.; ALDERA, H. \& ALKHATEEB, M. A. Ghrelin improves the fine structure of atrial natriuretic factor (ANF) granules and intercalated disc junctions in experimentally-induced myocardial infarction in rats. Int. J. Morphol., 36(3):1031-1042, 2018.

\& Griendling, 2002; Dröge, 2002). Indeed, ROS induce a state of oxidation that can lead to cellular membrane injury with the consequent alteration in metabolic processes.

Recently, drugs that offer cardioprotective effects have been studied but few have made it to clinical use, perhaps due to animal model choices for studying drug effects as well as myriad side effects and limited efficacy (Gower et al., 2003; Bolli et al., 2004). Fumaric acid, a tricarboxylic acid cycle small molecule metabolite, may offer myocardial protection via activation of the Nrf2 which is a basic leucine zipper protein that regulates the expression of antioxidant proteins that protect against oxidative damage triggered by injury and inflammation (Ashrafian et al., 2012). Thus, we speculate that similar compounds may also offer myocardial protection. A structural analog of fumaric acid, L-malate, is produced during biological metabolism of organic acids and serves as an important metabolic intermediate.

Ghrelin is a novel growth hormone-releasing peptide, which has recently been shown to exert beneficial cardiac effects on chronic heart failure (CHF). Moreover, ghrelin inhibited the inflammatory response, as shown by decreased mRNA and protein levels of interleukin (IL)-1beta and tumornecrosis factor-alpha (TNF-alpha). Subsequently, the expression of matrix metalloproteinase (MMP)-2 and MMP9 were also inhibited by ghrelin injection. Ghrelin alleviates LV dysfunction and ventricular remodeling in post-MI rats. This suggests that the beneficial effects of ghrelin on $\mathrm{CHF}$ may result from an inhibition of the inflammatory response (Huang et al., 2009). Post-MI in rats, ghrelin accounted for its anti-apoptotic effect, enhanced cardiac function, and inhibits cardiac fibrosis during cardiac remodeling (Eid et al., 2018).

Atrial natriuretic factor (ANF) was isolated from the atrium by de Bold et al. (1981) (De Bold et al., 2001), and since then, brain natriuretic peptide, C-type natriuretic peptide, dendroaspis natriuretic peptide, micrurus natriuretic peptide, and ventricular natriuretic peptide have also been found. These peptides are actually distributed all over the body, not only in the heart (Lai et al., 2002; Cayli et al., 2002; Zhao et al., 2003). ANF regulates a variety of physiological functions, including natriuresis, diuresis, and vasodilatation. Although ANF is synthesized primarily in the heart as a cardiac hormone, are also expressed in numerous extracardiac tissues (e.g. lung, thymus, and gastrointestinal tract tissues) suggests that ANF may play an important role as a regional autocrine and/or paracrine regulatory peptide in extracardiac tissues (Peng et al., 2003). By using immunohistochemistry and in situ hybridization, it has been found that ANF gene expression is localized in the rat gastric antrum in enterochromaffin cells (EC cells) in the lower portion of the antropyloric glands (Gerbes et al., 1991; Gower et al., 2000, 2003).
Cardiac intercalated discs (IDs) incorporate numerous molecular complexes that, besides the transmission of electrical and biochemical signals serve as a linkage between cytoskeletons of adjacent cardiomyocytes to provide structural support of always mechanically stressed myocardial tissue. Because of those critical functionalities, disturbance in molecular components of IDs results in cardiomyopathy (Rampazzo et al., 2014). In addition, detailed knowledge about the physiology of ID proteins may broaden therapeutically opportunities in clinical cardiology.

Therefore, the present investigation was aimed to assess the potential of ghrelin as a cardio protective agent in the induced MI of the animal model that epitomizes the experimental evaluation of cardio protective agents. The current study also elucidates the mechanism of its therapeutic efficacy, by substantiating the ultrastructural study on cardiomocytes ANF, IDs and apoptosis.

\section{MATERIAL AND METHOD}

Animals: Sixty healthy Sprague-Dawley male rats (260 \pm $20 \mathrm{gm}$ ) were obtained from, housed and treated in the animal facility of the college of medicine at King Khalid University, Abha, Saudi Arabia. Animals were housed in their specific cages under 12-h light/dark cycle at $23 \pm 3{ }^{\circ} \mathrm{C}$ and 40-65\% humidity and fed semipurified normal control diet (AIN-93G diet) and had free access to drink water. All experimental procedures done in this study were approved by Research Ethics Committee of King Khalid University, Abha, Saudi Arabia which follow the guidelines established by the US National Institutes of Health (National Research Council, 1996).

Experimental design: All treatments of the current study were administered orally and continued for 21 days on daily basis. Rats were randomly divided into three groups $(n=20 /$ group) as follows: the first sham operated control group were the rats that underwent the same surgical procedure used to induced MI but without tying the left anterior descending coronary artery (LAD) and received normal saline $(0.5 \mathrm{ml})$ as vehicle; the second MI model group were rats with LAD ligation and received normal saline $(0.5 \mathrm{ml})$ and the third one was the MI+ghrelin group were rats that were exposed to surgery to induce MI but received ghrelin $(100 \mu / \mathrm{kg}$, orally, 2x/day). Synthetic rat's ghrelin (C147H245N45O42, Cat No. ab120231, Sigma Aldrich, UK) was used in this study and always prepared freshly every day in distilled water to the desired volume, to desired groups; ghrelin was administered one day after the surgical procedures. The dose and rout of ghrelin administration were selected based on the reports of 
EID, R. A.; ZAKI, M. S. A.; ALGHAMDI, M. A.; AL-SHRAIM, M.; EL-KOTT, A. F.; AL-HASHEM, F. H.; ALDERA, H. \& ALKHATEEB, M. A. Ghrelin improves the fine structure of atrial natriuretic factor (ANF) granules and intercalated disc junctions in experimentally-induced myocardial infarction in rats. Int. J. Morphol., 36(3):1031-1042, 2018.

confirmed such dose is required to achieve minimal cardioprotective and anti-apoptotic effect of ghrelin in various cardiovascular diseases such as chronic heart failure (Nagaya et al., 2004) and 2 weeks post-MI (Soeki et al., 2008).

Induction of MI by LAD ligation: MI was established by left anterior descending coronary artery (LAD) ligation. In brief, animals were anesthetized with $1 \%$ solution of sodium pentobarbital $(50 \mathrm{mg} / \mathrm{kg}$ ) and ventilated (Harvard rodent ventilator, model 863, Harvard Apparatus, Holliston). To prevent corneal injury, an eye lubricant ointment was applied to both eyes in order to prevent dryness. A left thoracotomy was performed and the heart was exposed and ligated using 8-0 polypropylene suture. Then, the chest was closed in a three-layer closure (sternum, pectoral's muscle, and skin) with 6-0 sutures, after the air was completely vented out. Successful MI was confirmed by apparent ST-segment elevation in electrocardiogram recorded by the Power Lab system (AD instrument, Australia) using 3 limbs electrodes. The entire procedure usually required 15-25 $\mathrm{min}$ and was usually done by the same surgeon. After surgery and during recovery, the rat was kept in a humidified $37^{\circ} \mathrm{C}$ incubator. Sham-operated animals underwent the same surgical procedure without the LAD ligature. Then, all rats received routine intramuscular injections of buprenorphine- $\mathrm{HCl}(0.2$ $\mathrm{mg} / \mathrm{kg}$ ) for analgesia and penicillin $(1000 \mathrm{U})$ to prevent infection.

Transmission electron microscopy (TEM) procedures: For TEM, right atrium (RA) specimens were obtained from the area of maximum infracts of hearts of both control and treated rats were immediately preserved in $2.5 \%$ gluteraldehyde, trimmed and diced into 1 cubic millimeter sizes, fixed in gluteraldehyde fixative in $0.1 \mathrm{M}$ sodium cacodylate buffer, $\mathrm{pH} 7.4$, and placed in a thermal box cooled to $4{ }^{\circ} \mathrm{C}$ for $2 \mathrm{~h}$. They were post-fixed in $1 \%$ osmium tetraoxide in a sodium cacodylate buffer and then dehydrated in ascending series of ethanol and embedded in Spurr's resin. Ultrathin sections stained with uranyl acetate and lead citrate were examined by transmission electron microscope (JEM1011, Jeol Co., Japan) at $80 \mathrm{KV}$ in the Electron Microscopy Unit, Pathology Department, College of Medicine, King Khalid University (Bancroft \& Gamble 2002).

\section{RESULTS}

Group I (Sham-operated control rats). Electron microscopic examination of the sections from the rat atria of the control group showed normal architecture. The myocardial cells of the control group contained aggregations of small electron-dense granules, i.e. atrial (specific) granules
(ANF). They occurred in clusters of various sizes. These accumulations have been observed in the central parts of the cell close to the nucleus, but most often they occurred in sarcoplasmic pockets between the plasma membrane and the peripheral myofibrils. The granules were spherical. The content of the granules was mostly electron-dense material, appearing nearly black when double-stained with uranyl acetate and lead citrate. The sarcoplasm in these parts of the cells had a foamy appearance with no specific cellular structures visible and was always located close to the granule aggregation (Fig. $1 \mathrm{~A}$ and $\mathrm{B}$ ).

Intercalated discs, numerous in the rat atrium of the sham-operated group, intersected the myocardial cells from one intercellular space to the next (Fig. $3 \mathrm{~A}$ and B). The discs were composed of longitudinal segments running parallel to the myofilaments and transverse segments intersecting the myofibrils. The transverse segments followed either a straight or a zigzag course across the myofibril. Two structural modifications of the membranes were present, the fascia adherence and the macula adherence (desmosome). The intercellular gap was occupied by fine filaments which often seemed to cross the space and to have a close relationship to the apposed membranes (Fig. 3A and B). Desmosomes, singly or in groups, were also observed along the longitudinal segments of the disc, often at the level of the Z-lines. The present study revealed a close relationship between the intercalated discs and the Z-lines. Nexuses were small junctions often located adjacent to the transverse segments of the discs (Fig. $3 \mathrm{~A}$ and B).

In this study we noted the presence of myofibrils parallel to each other and their preserved sarcomeres with clear bands $(\mathrm{Z}$ and $\mathrm{H})$. The myofibrils alternating with the mitochondria can also be seen, a feature common in striated cardiac tissue. Also, the mitochondria with electron-dense matrix and its external and internal membrane (cristae mitochondrial) are intact. An intact nucleus with a normal distribution of chromatin is also seen (Fig. 1 A and B) (Fig. $3 \mathrm{~A}$ and B). A normal blood capillary with an endothelium consisting of a single layer of endothelial cell with a large irregular nucleus was also noticed (Fig. 5 A).

Group II (Myocardial infarction treated rats). Sections from atria of rats after induction of MI showed evident ultrastructural changes of the heart tissues. Rat's atrial myocytes showed atrionatriuretic factor (ANF) granules, which were few and disintegrated in most of the granules (Fig. $1 \mathrm{C}$ and D) (Fig. $2 \mathrm{~A}$ and B). Intercalated discs, numerous in the rat atrium of the MI treated group showed marked irregularity of its fascia adherence and desmosomes are observed. They were also loss of gap junction (nexus) (Fig. $3 \mathrm{C}$ and D) (Fig. $4 \mathrm{~A}$ and B). The extracellular matrix 


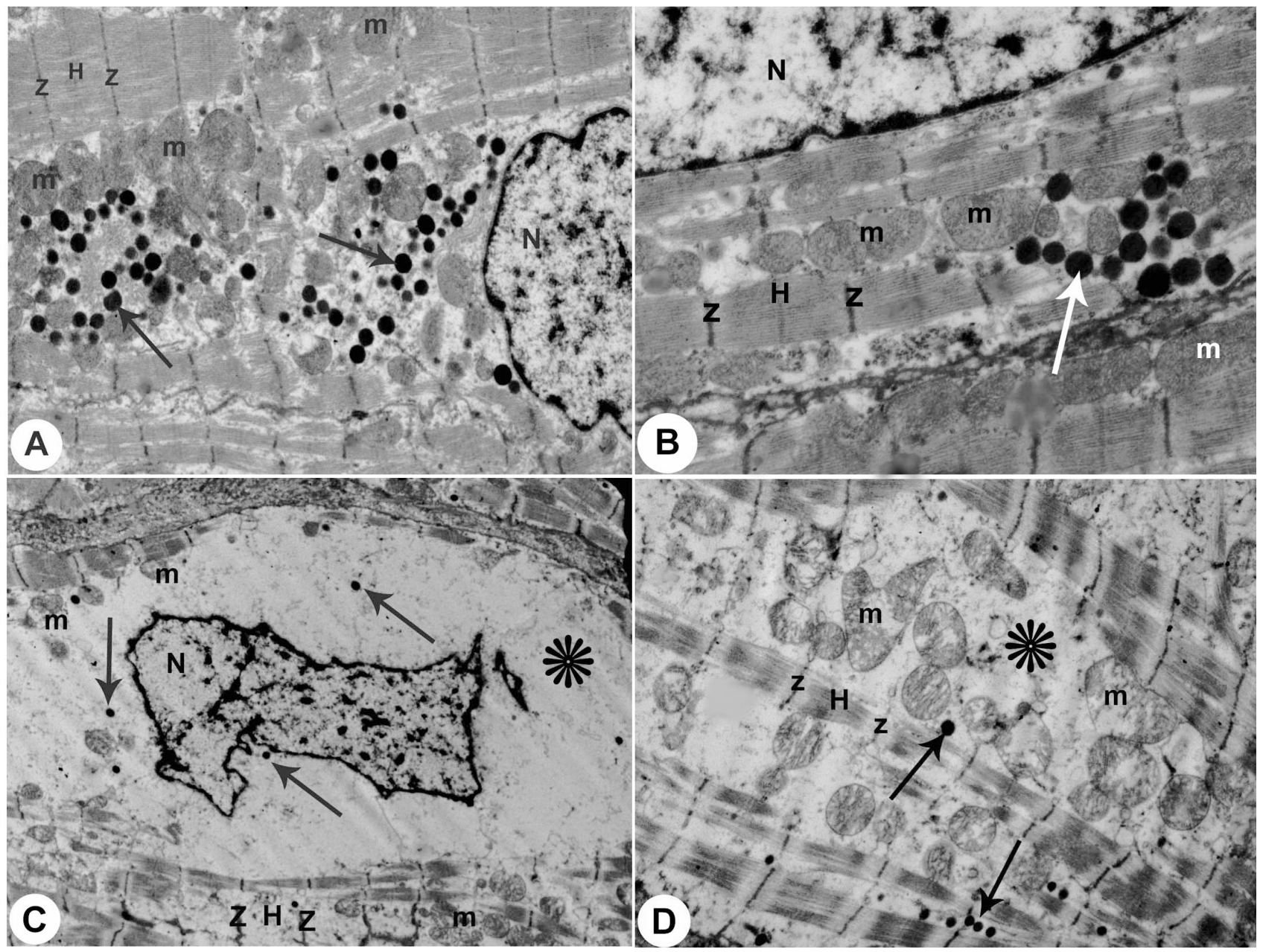

Fig. 1.Transmission electron micrographs of the right atrium obtained from all group of rats. (Atrionatriuretic factor (ANF) granules) A and B. Sham-operated treated rats atrial myocyte showing dense cytoplasm filled with very dense electron granules, with sparsely granular and homogeneous content called atrionatriuretic factor (ANF) granules (arrows). The myofibrils are parallel to each other and their preserved sarcomeres with clear bands $(\mathrm{Z}$ and $\mathrm{H})$. Also, the mitochondria $(\mathrm{m})$ and nucleus $(\mathrm{N})$ with a normal distribution of chromatin is also seen (X10000 \& X20000 respectively). C and D. MI group rat's atrial myocyte showing few atrionatriuretic factor (ANF) granules (arrows) are also observed, degenerated cytoplasm (asterisks) of myofibrils with fragmentation of muscle bands $(\mathrm{Z}$ and $\mathrm{H})$ and degenerated mitochondria (m) with disoriented and dissoluted cristae, breaks in the outer mitochondrial membrane, disassembly of nuclear lamina, markedly clumped chromatin randomly dispersed in the nuclei (N) with irregular of its membrane (X10000 \& X20000 respectively).

between the cardiomyocytes showed disorganized and degenerated myocytes are noted with the fragmentation of muscle bands ( $\mathrm{Z}$ and $\mathrm{H})$. There was no default in the alignment of cardiomyocytes myofibrils, leading to a structural impairment in contractile units. Another feature often observed in the MI group myocytes was the loss of mitochondrial integrity. These organelles are presented swollen, with disrupted membranes, highlighting the reduction of mitochondrial cristae and loss of electron-dense matrix. Besides the mentioned alterations, endothelial cells and myocytes were observed, displaying highly condensed chromatin associated with the nuclear envelope. This characteristic is an indication that they may be in the apoptosis process (Fig. $1 \mathrm{C}$ and D) (Fig. $2 \mathrm{~A}$ and B).
In this current work, the degenerated cytoplasm of myofibrils with the fragmentation of muscle bands and degeneration, swollen mitochondria with disoriented and dissolution of cristae, flocculent density deposition, breaks in the outer mitochondrial membrane, disassembly of the nuclear lamina, markedly clumped chromatin randomly dispersed in the nuclei (Fig. 1 C and D) (Fig. 2 A and B). In this group, rats showed damaged blood capillaries with endothelium, Deposition of collagen fibrils and damaged nerve endings were also seen in the interstitium (Fig. 5 B and C).

Group III (Co-treated rats with Myocardial infarction and ghrelin treated rats). Concomitant administration of ghrelin with MI treated rats showed a considerable protection 

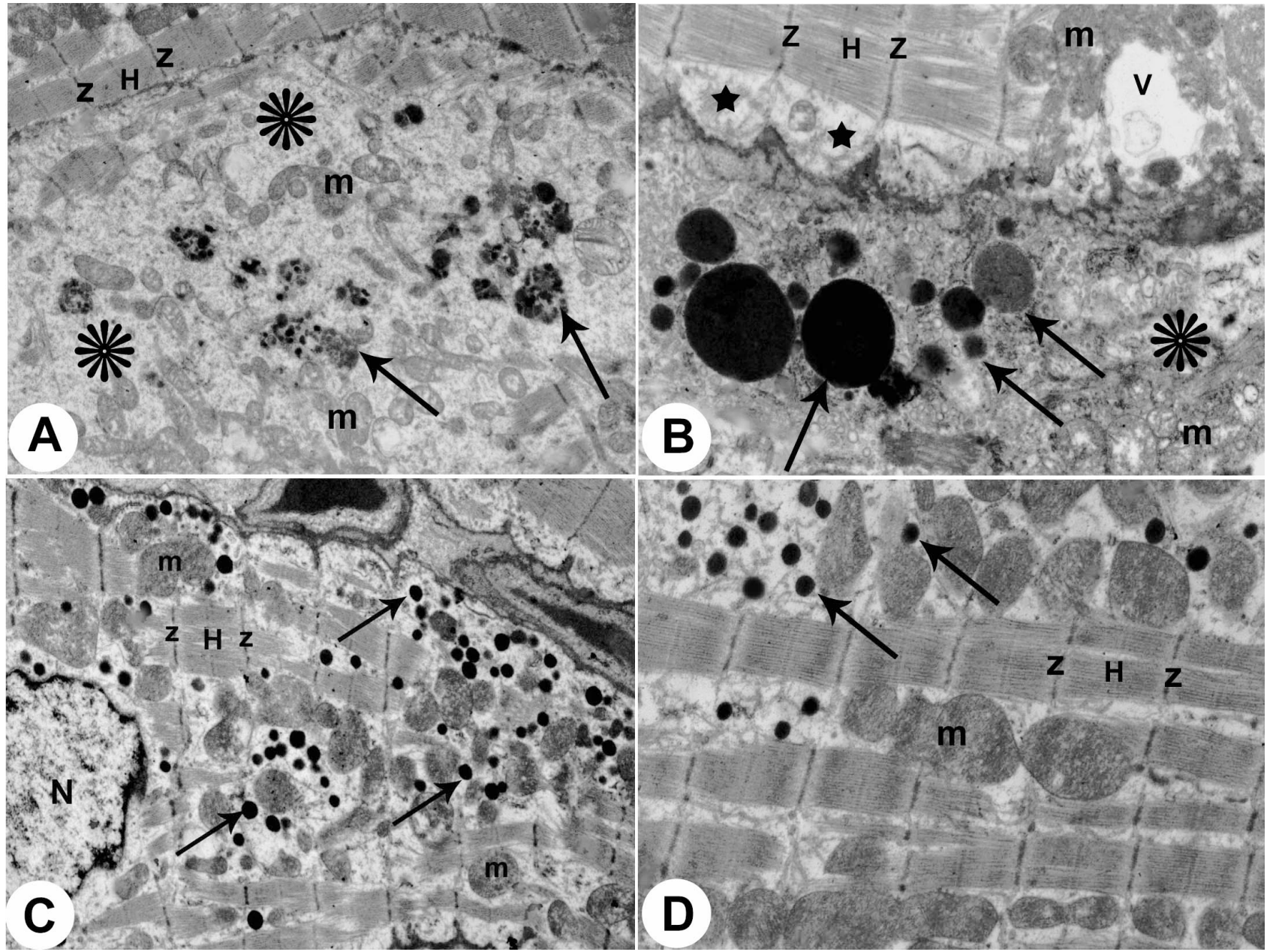

Fig. 2.Transmission electron micrographs of the right atrium obtained from all group of rats. (Atrionatriuretic factor (ANF) granules). A and B. MI group rat's atrial myocyte showing atrionatriuretic factor (ANF) granules (arrows), which are few and disintegrated in most of the granules which have different size molecules, degenerated cytoplasm (asterisks) of myofibrils with a fragmentation of muscle bands $(\mathrm{Z}$ and $\mathrm{H})$. Pleomorphic mitochondria $(\mathrm{m})$ and blebs (stars) are seen in the myocardial cells. (X20000). C and D. Co-treated rats with MI and ghrelin group showing regions of normal architecture with well-preserved integrity and striated pattern of clear bands $(Z$ and $H)$, nucleus $(\mathrm{N})$ and mitochondria $(\mathrm{m})$. Atrionatriuretic factor (ANF) granules (arrows) are also seen within normal distribution. (X10000 \& X20000 respectively).

of the atrial tissues. Ultrastructural study of the atrial tissue of this group showed that the sarcoplasm was occupied by normal myofibrils with clear striations and others had been with minor disruption. Normal distribution of atrionatriuretic factor (ANF) granules (Fig. $2 \mathrm{C}$ and D), intact intercalated disc with clear identification of fully formed fascia adherence and desmosomes (Fig. $4 \mathrm{C}$ and D) with a reconstruction of gap junction (nexus) were also noticed. Well preserved mitochondrial integrity (preserved cristae, normal size, and shape), nucleus chromatin arrangement and striated pattern of clear bands ( $\mathrm{Z}$ and $\mathrm{H}$ ) were noticed in comparison to the MI group. Normal blood capillary with intact endothelium and clear nucleus with a normal distribution of its chromatin content was also noticed in this group of the experiment (Fig. 5D) (Table I).

\section{DISCUSSION}

Atrial myocytes after myocardial infarction is often associated with subsequent heart failure, which could lead to a fatal outcome. In a rat model of experimental myocardial infarction, peripheral ghrelin administration attenuated myocyte dysfunction and remodeling was examined as described below.

The electron micrographs of the atrial myocytes of the sham-operated control group of this study showed the presence of very dense electron granules, with sparsely granular and homogeneous content, coated with a double membrane. Most of their granules are located near the nu- 


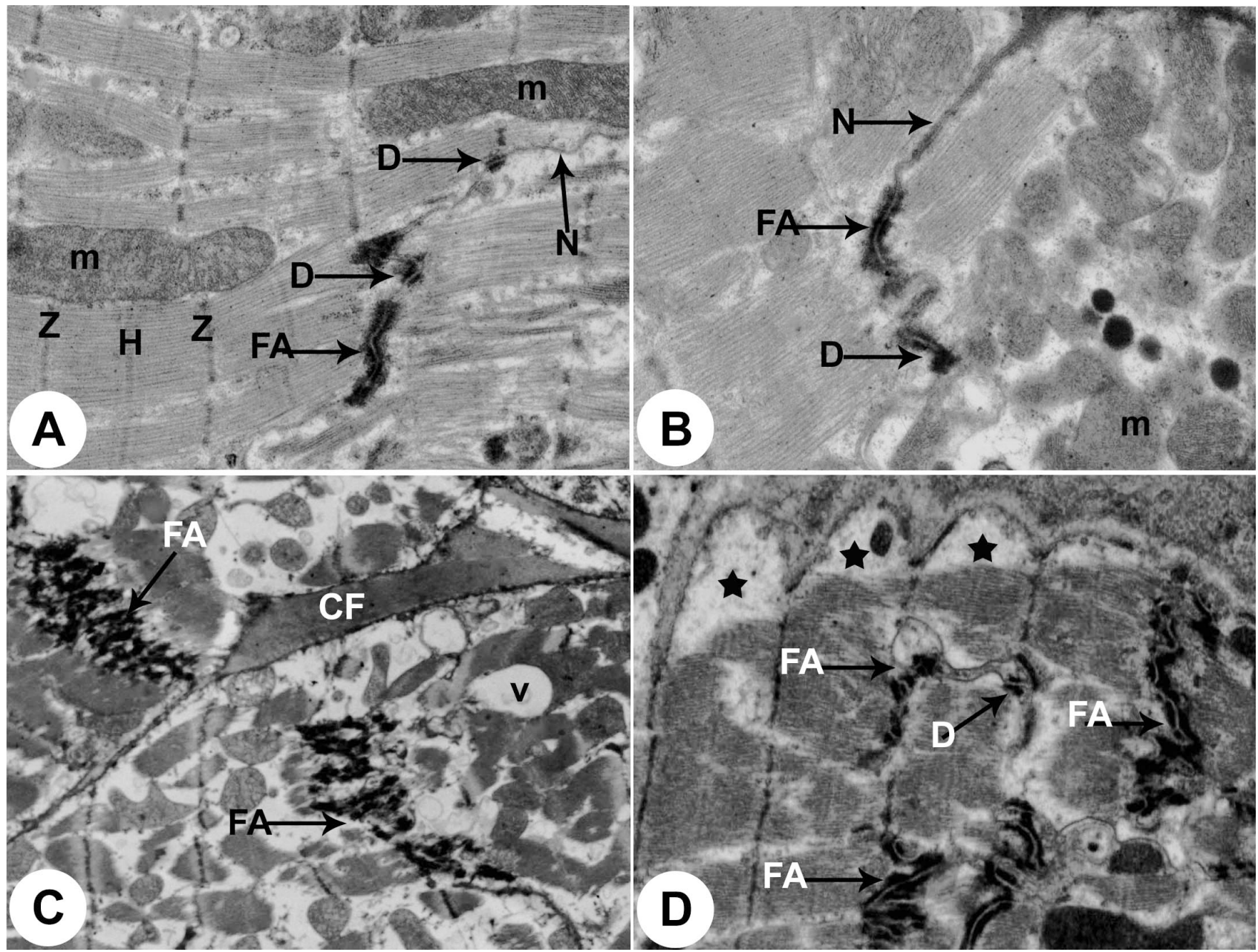

Fig. 3. Transmission electron micrographs of the right atrium obtained from all group of rats. (Intercalated discs) A and B. Shamoperated control rat's atrial myocyte showing normal intercalated disc. Intercalated discs are the membrane sites where individual cardiomyocytes are connected to each other. Fascia adherens- (FA), desmosomal- (D), and gap junctions (nexus) (N) are situated in the intercalated disc. Healthy myofibrils and its striated pattern with clear bands ( $\mathrm{Z}$ and $\mathrm{H})$ and intact mitochondria $(\mathrm{m})$ are also seen. (X10000 \& X20000 respectively). C and D. MI group rats showing damaged intercalated discs. The marked irregularity of fascia adherens (FA) and desmosomes (D) are observed. We notice also a loss of gap junction (nexus). Degenerated myofibrils with a fragmentation of muscle bands ( $\mathrm{Z}$ and $\mathrm{H}$ ) with blebs (stars) in myocardial apoptotic cells, pleomorphic mitochondria (m), vacuoles (V) and deposition of collagen fibrils (CF) are also seen (X10000 \& X20000 respectively).

clear poles, among mitochondria but there is a small number near the plasma membrane (Gama \& Rodrigues de Souza, 2006). Previous studies from the fifties (Kisch, 1956) in guinea pig hearts have shown the presence of specific atrial granules which has been functionally considered as an activator of sodium and water excretion and blood pressure reduction (De Bold et al., 1981; Forssmann et al., 1984; Skepper \& Navaratnam, 1988; Jiao etal., 1993; Yoshihara et al., 1998). Those granules, in the myocytes of the auricles and in the atria, contain a peptide hormone called atrial natriuretic factor (ANF). The atrial walls are distended under conditions of hypervolemia or blood pressure increase would promote an increase in the ANF percentage in the blood (Veress \& Sonnerberg, 1984).
Sections from atria of rats after induction of MI showed evident ultrastructural changes of the heart tissues. Rat's atrial myocytes showed atrionatriuretic factor (ANF) granules, which were few and disintegrated in most of the granules. After de Bold and co-workers identified 'atrial natriuretic factor' (ANF) as a major constituent of rat atrial granules with a potent diuretic and natriuretic effects (de Bold et al., 1981; Cantin \& Genest, 1985), ANF were soon recognized as a ubiquitous hormonal system in both mammalian and non-mammalian vertebrates. Therefore, they increase the efficiency of information and 'memory' of the heart by interacting with other neuropeptides and endocrines produced by other cell components (Hirose et al., 1998; Zhang et al., 2005), improving the zonal capacity to detect 

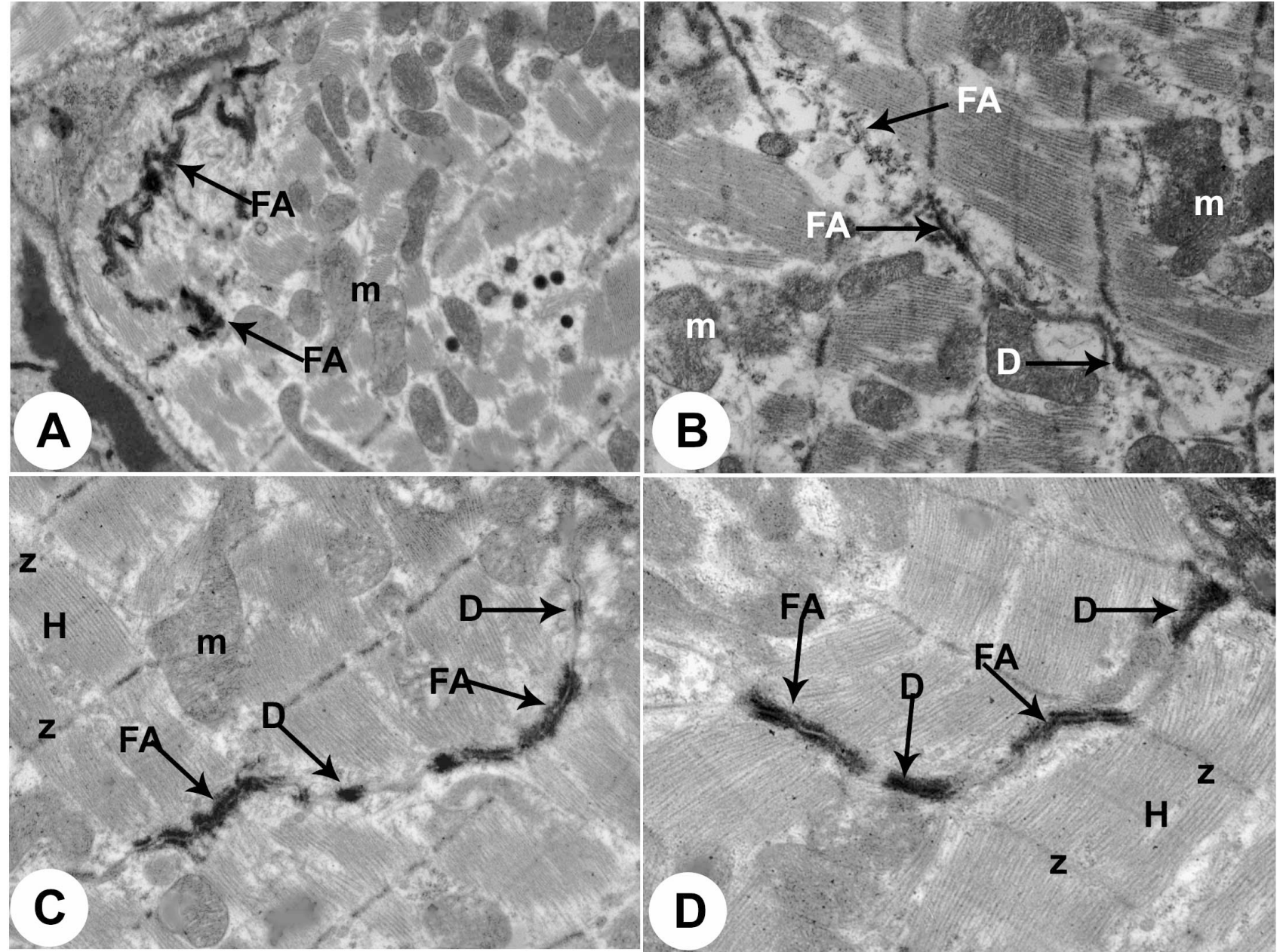

Fig. 4. Transmission electron micrographs of the right atrium obtained from all group of rats. (Intercalated discs) A. \& B. MI group rats showing damaged intercalated discs. The observed irregularity of facia adherens (FA) and desmosomes (D) are observed. We notice also a loss of gap junction (nexus). Degenerated myofibrils with a fragmentation of muscle bands $(\mathrm{Z}$ and $\mathrm{H})$ and pleomorphic mitochondria (m) are also seen. (X10000 \& X20000 respectively). C. \& D. Co-treated rats with MI and ghrelin group showing intact intercalated disc. Note fascia adherens (FA) and desmosomes (D). Reconstruction of gap junction (nexus) is also noticed. Healthy myofibrils and its striated pattern with clear bands $(\mathrm{Z}$ and $\mathrm{H})$ and mitochondria $(\mathrm{m})$ are also seen. (X10000 \& X20000 respectively).

and respond to variations in the internal and external environment. The enhancement of ANF synthesis in the cells to overcome cardiac overload, as in advanced heart failure, led to a reduction of the granule size with subsequent decrease in the levels of atrial ANF mRNA and plasma ANF in the course of the down-regulation (Mifune et al., 1991, 1992, 1996).

Intercalated discs, numerous in the rat atrium of the MI treated group showed marked irregularity of its fascia adherence and desmosomes are observed. They were also loss of gap junction (nexus). Disturbances of the proteins at IDs deteriorate cardiac function and morphology, one of these is afadin, which is one of adherent junction components that is expressed ubiquitously including IDs (Zankov et al.,
2017). a - E- catenin is a cell adhesion protein, located within the adherent junction, thought to be essential indirectly linking the cadherin-based adhesion complex to the actin cytoskeleton. Although a-E-catenin is expressed in the adherent junction of the IDs in dilated cardiomyopathy models, its role in the myocardium remains unknown (Sheikh et al., 2006). Gap junctions form pathways for direct intercellular communication, a function of particular importance for morphogenetic signaling during development. The confocal scanning laser microscopy is used to understand the structural basis of the function of gap junctions in the normal adult, developing and diseased hearts (Severs et al., 1993). Adherent junctions and desmosomes are responsible for coupling myocytes in the heart and are found closely opposed to gap junction plaques 


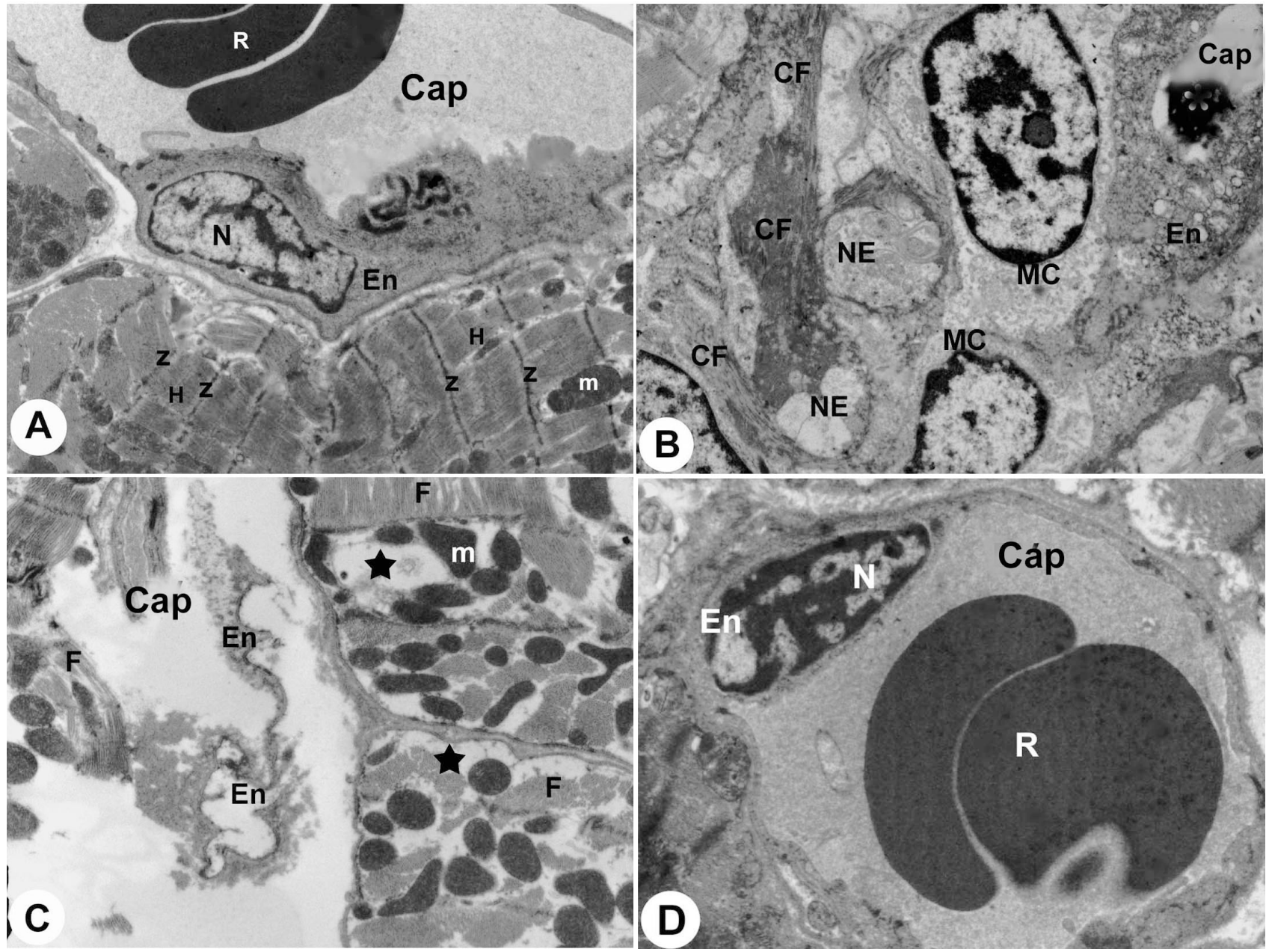

Fig. 5. Transmission electron micrographs of the right atrium obtained from all group of rats. (Blood capillaries) (10000X). Shamoperated control rat's atrial myocyte showing a normal blood capillary (Cap) with intact endothelial cells (En), nucleus (N) and erythrocytes (R). Note normal myocyte structure with its striated pattern with clear bands ( $\mathrm{Z}$ and $\mathrm{H}$ ) and mitochondria (m). \& C. MI group showing damaged blood capillaries (Cap) with endothelium (En), degenerated cytoplasm (stars) of myofibrils with fragmentation of muscle fibers $(\mathrm{F})$ and mitochondria (m). Deposition of collagen fibrils (CF), damaged nerve endings (NE) and monocytes (MC) are also seen in the interstitium. D. Co-treated rats with MI and ghrelin group showing normal blood capillary (Cap) with intact endothelium (En) with its nucleus $(\mathrm{N})$ and erythrocytes $(\mathrm{R})$ in its lumen and nucleus $(\mathrm{N})$.

at the intercalated discs of cardiomyocytes. It is not known whether loss of cardiac gap junctions, such as described in cardiac disease states, may influence the expression patterns of other intercalated disc-associated proteins (Gutstein $e t$ al., 2003).

In the MI group of this study, a degenerated cytoplasm of myofibrils with a fragmentation of muscle bands and degeneration, swollen mitochondria with disoriented and dissoluted cristae, flocculent density deposition, breaks in the outer mitochondrial membrane, disassembly of the nuclear lamina, markedly clumped chromatin randomly dispersed in the nuclei. In this group, rats showed damaged blood capillaries with endothelium, Deposition of collagen fibrils, damaged nerve endings were also seen in the interstitium. The evidence of apoptosis, confirm the molecular assay findings, which the conversion of procaspase- 3 to cleaved caspase- 3 is noted. Although the electron microscopy did not reveal a constant chromatin condensation and nuclear fragmentation (cell death), the cardiomyocyte is deteriorated (Communal et al. 2002). This could indicate that the myocytes are in a proapoptotic stage, while the morphologic nuclear changes do not happen (Narula et al., 1999). Dogan et al. (2010) also identified in rats, positive apoptotic cardiomyocytes in the heart irradiated with a dose of $20 \mathrm{~Gy}$. The endothelial cell injury appears to be the main event responsible for triggering late damage. Because of low blood perfusion, late myocardial 


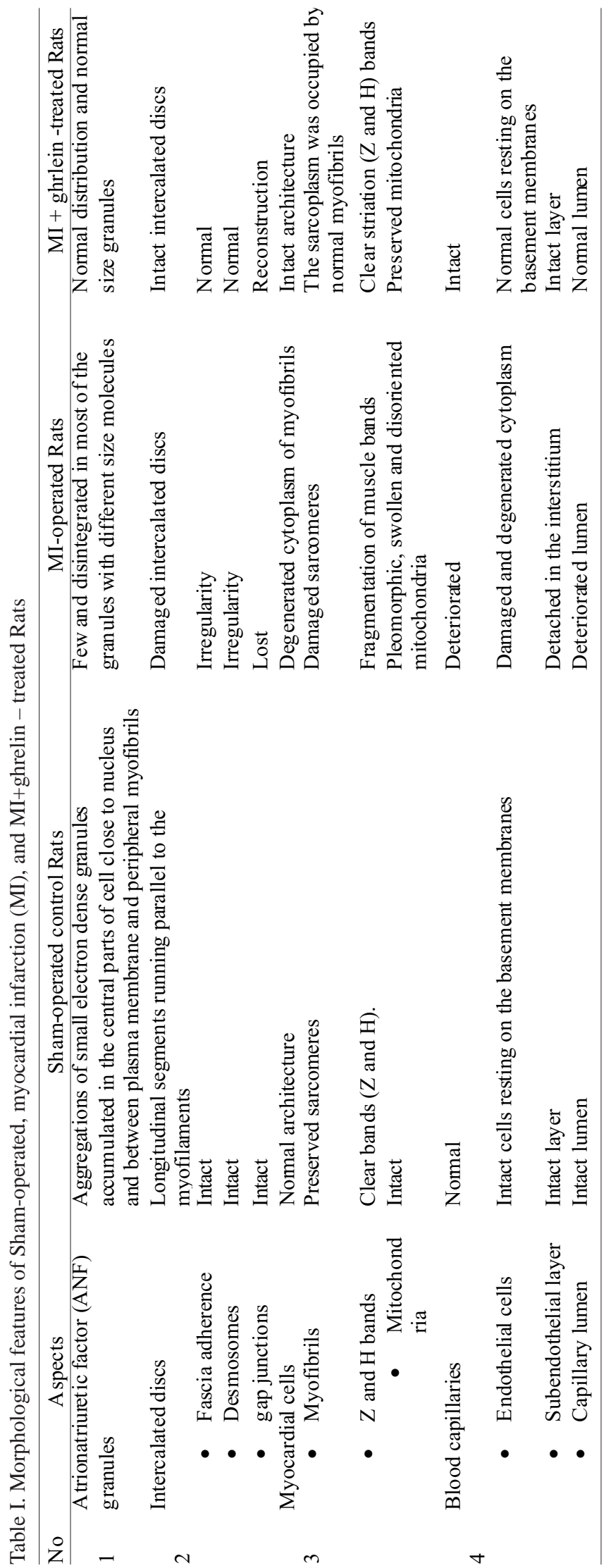

degeneration has been observed by some authors and it is associated with a progressive increase of fibrosis and cardiomyocytes apoptosis (Wang et al., 2007; Jelonek et al., 2011). In addition, cardiac fibrosis, this is one of the main biologic determinants of poor prognosis in heart failure and strongly associated with severe arrhythmias, diastolic dysfunction, and sudden death.

Compaction of nuclear chromatin into sharply circumscribed, uniformly dense masses that abut the nuclear envelope was seen in occasional cardiocytes was clearly observed in this study. These cells also exhibit nuclear fragmentation and chromatin condensation with lysis of the nucleolemma whereas the sarcolemma remains intact until the cell is engulfed by local macrophages with avoidance of inflammation (James, 1994). Wyllie (1987) proposed four cardinal elements involved in apoptosis. These included (Perennec et al., 1988) cell volume reduction (Baandrup et al., 1981), nuclear chromatin condensation in early stages of apoptosis (Knieriem, 1978), changes in the cell membrane.

Concomitant administration of ghrelin with MI treated rats of the present study showed a considerable protection of the atrial tissues. Ultrastructural study of the atrial tissue of this group showed that the sarcoplasm was occupied by normal myofibrils with clear striations and others had been with minor disruption. Normal distribution of atrionatriuretic factor (ANF) granules, an intact intercalated disc with clear identification of fully formed fascia adherence and desmosomes with a reconstruction of gap junction (nexus) were also noticed. Normal blood capillary with intact endothelium and clear nucleus with a normal distribution of its chromatin content and well preserved mitochondrial integrity (preserved cristae, normal size, and shape), nucleus chromatin arrangement and striated pattern of clear bands $(\mathrm{Z}$ and $\mathrm{H})$ in comparison to the MI group were also noticed.

Ghrelin, a growth-hormone secretagogue, stimulates muscle anabolism, has anti-inflammatory effects, promotes vasodilatation and improves cardiac performance (Rocha et al., 2017). Ghrelin has been shown to have protective effects against MI by inhibiting cardiomyocyte and endothelial cell apoptosis (Baldanzi et al., 2002), and to improve left ventricular function during ischemia-reperfusion (I/R) injury (Frascarelli et al., 2003). In rats with heart failure (HF), ghrelin improves LV dysfunction and attenuates the development of cardiac cachexia (Nagaya et al., 2001b). Similarly, in short-term studies, ghrelin improves cardiac 
EID, R. A.; ZAKI, M. S. A.; ALGHAMDI, M. A.; AL-SHRAIM, M.; EL-KOTT, A. F.; AL-HASHEM, F. H.; ALDERA, H. \& ALKHATEEB, M. A. Ghrelin improves the fine structure of atrial natriuretic factor (ANF) granules and intercalated disc junctions in experimentally-induced myocardial infarction in rats. Int. J. Morphol., 36(3):1031-1042, 2018.

function and decreases systemic vascular resistance in patients with chronic HF (Nagaya et al., 2001c). In the vasculature, ghrelin exerts vasodilatory effects (Nagaya et al., 2001a) and possibly anti-inflammatory effects that may be of potential importance for the development of atherosclerosis (Dixit et al., 2004). Further evidence for a protective action of ghrelin against cardiac I/R was provided by the study by Chang et al. (2004), who showed that administration of ghrelin during reperfusion resulted in improvement in coronary flow, heart rate, left ventricular systolic pressure, and enhanced rates of left ventricular contraction and relaxation and reduced myocardial release of lactate dehydrogenase and myoglobin. These results would suggest not only functional improvement but also protection from tissue injury, which may be of important clinical significance.

Many drugs that offer cardioprotective effects have been studied, but few have made it to clinical use. Vitamin D has anti-inflammatory and antioxidant effects and can be demonstrated as a promising cardioprotective agent in MI (El-Gohary \& Allam, 2017). The arctigenin which is a potent antioxidant that found in certain plants may inhibit MI, and exhibits antioxidative and anti-inflammatory effects through regulation of the inducible nitric oxide synthase (iNOS), cyclooxygenase 2 (COX-2), phosphorylated-extracellular signal-regulated kinase $1 / 2$ (p-ERK1/2) and heme oxygenase 1 (HO-1) pathways in a rat model of AMI (Zhang \& Yang, 2018). Moreover, a structural analogue of fumaric acid, L-malate, is produced during biological metabolism of organic acids and serves as an important metabolic intermediate may protect against myocardial ischemia/reperfusion (I/R) injury in rats via anti-inflammatory and antioxidant activity and this may be associated with activation of the Nrf2/Keap1 antioxidant pathway (Ding et al., 2016).

\section{CONCLUSIONS}

The main finding of the present study is that ghrelin has a cardioprotective role in MI. Animals receiving ghrelin had improved cardiac structure. The present study demonstrates that ghrelin has potential to protect against MI by restoring endogenous antioxidants, preserving histopathology and ultrastructure of myocytes ANF, IDs and apoptosis. The findings of this study are suggestive of ghrelin as an adjunct in prophylaxis from MI or as a beneficial mediator in delaying the initiation, progression, and development of MI, in patients who are at risk of developing ischemic heart disease. However, for use in humans, further studies are warranted.

\section{ACKNOWLEDGMENTS:}

The authors extend their appreciation to the Deanship of Scientific Research at King Khalid University for funding this work through research groups program under grant number (R.G.P. 1/1/38)

EID, R. A.; ZAKI, M. S. A.; ALGHAMDI, M. A.; ALSHRAIM, M.; EL-KOTT, A. F.; AL-HASHEM, F. H.; ALDERA, H. \& ALKHATEEB, M. A. La grelina mejora las estructuras finas de los gránulos de factor natriurético atrial (ANF) y las uniones intercaladas de disco en el infarto de miocardio inducido experimentalmente en ratas. Int. J. Morphol., 36(3):1031-1042, 2018.

RESUMEN: La grelina es un nuevo péptido liberador de hormona de crecimiento administrado para tratar el infarto de miocardio (IM). Sin embargo, el mecanismo subyacente de sus efectos protectores contra el IM aún no se conocen. Se incluyeron un total de 60 ratas macho Sprague Dawley saludables. En el grupo control se incluyeron ratas que fueron sometidas a una cirugía utilizada para inducir el IM, pero sin ligar la arteria coronaria descendente anterior izquierda (ACDAI) y recibieron suero fisiológico normal $(0,5 \mathrm{ml})$ como vehículo; el segundo grupo modelo de IM fueron ratas con ligadura de ACDAI y recibieron suero fisiológico normal $(0,5 \mathrm{ml})$; el tercer grupo estuvo formado por ratas con IM + grelina, expuestas a la cirugía para inducir IM pero luego recibieron grelina $(100 \mathrm{~m} / \mathrm{kg}$, oralmente, 2x/día). Al final del experimento, 21 días después del infarto de miocardio, los animales fueron sacrificados y procesados para el estudio ultraestructural. Nuestro experimento mostró que la grelina inhibe la apoptosis de los cardiomiocitos. La administración concomitante de grelina en ratas con IM parece indicar una protección considerable de los tejidos atriales. Además, el estudio reveló que el sarcoplasma estaba ocupado por miofibrillas normales con estriaciones claras y otras con una alteración menor. Se encontró una distribución normal de los gránulos del factor natriurético atrial (FNA) e integridad mitocondrial bien conservada (crestas conservadas, tamaño y forma normales), disposición de la cromatina del núcleo y patrón estriado de bandas claras ( $\mathrm{Z}$ y H) en comparación con el grupo IM. También se observó un disco intercalado intacto con una clara identificación de la adherencia de la fascia completamente formada y desmosomas con una reconstrucción de la unión gap (nexo). Los miocitos atriales, después de un infarto de miocardio, a menudo se asocian con insuficiencia cardíaca posterior, que podría conducir a un desenlace fatal. En un modelo de rata de infarto de miocardio experimental, la administración de grelina periférica atenuó la disfunción de miocitos, con conservación del desmosoma, adherencia y unión de la brecha del disco intercalado y una distribución normal de los los gránulos de FNA.

PALABRAS CLAVE: Grelina; Infarto de miocardio; Factor natriurético atrial; Uniones intercaladas de discos; Ratas. 


\section{REFERENCES}

Ashrafian, H.; Czibik, G.; Bellahcene, M.; Aksentijevic, D.; Smith, A. C.; Mitchell, S. J.; Dodd, M. S.; Kirwan, J.; Byrne, J. J.; Ludwig, C.; Isackson, H.; Yavari, A.; Støttrup, N. B.; Contractor, H.; Cahill, T. J.; Sahgal, N.; Ball, D. R.; Birkler, R. I.; Hargreaves, I.; Tennant, D. A.; Land, J.; Lygate, C. A.; Johannsen, M.; Kharbanda, R. K.; Neubauer, S.; Redwood, C.; de Cabo, R.; Ahmet, I.; Talan, M.; Günther, U. L.; Robinson, A. J.; Viant, M. R.; Pollard, P. J.; Tyler, D. J. \& Watkins, H. Fumarate is cardioprotective via activation of the Nrf2 antioxidant pathway. Cell Metab., 15(3):361-71, 2012.

Baandrup, U.; Florio, R. A.; Roters, F. \& Olsen, E. G. Electron microscopic investigation of endomyocardial biopsy samples in hypertrophy and cardiomyopathy. A semiquantitative study in 48 patients. Circulation, 63(6):1289-98, 1981

Baldanzi, G.; Filigheddu, N.; Cutrupi, S.; Catapano, F.; Bonissoni, S.; Fubini, A.; Malan, D.; Baj, G.; Granata, R.; Broglio, F.; Papotti, M.; Surico, N.; Bussolino, F.; Isgaard, J.; Deghenghi, R.; Sinigaglia, F.; Prat, M.; Muccioli, G.; Ghigo, E. \& Graziani, A. Ghrelin and des-acyl ghrelin inhibit cell death in cardiomyocytes and endothelial cells through ERK1/ 2 and PI 3-kinase/AKT. J. Cell Biol., 159(6):1029-37, 2002.

Bancroft, J. D. \& Gamble, M. Theory and Practice of Histological Techniques. $5^{\text {th }}$ ed. New York, Churchill Livingstone, 2002. pp.76.

Bolli, R.; Becker, L.; Gross, G.; Mentzer, R. Jr.; Balshaw, D.; Lathrop, D. A. \& NHLBI Working Group on the Translation of Therapies for Protecting the Heart from Ischemia. Myocardial protection at a crossroads: the need for translation into clinical therapy. Circ. Res., 95(2):125-34, 2004.

Cantin, M. \& Genest, J. The heart and the atrial natriuretic factor. Endocr. Rev., 6(2):107-27, 1985.

Cayli, S.; Ustünel, I.; Celik-Ozenci, C.; Korgun, E. T. \& Demir, R. Distribution patterns of PCNA and ANP in perinatal stages of the developing rat heart. Acta Histochem., 104(3):271-7, 2002.

Chang, L.; Ren, Y.; Liu, X.; Li, W. G.; Yang, J.; Geng, B.; Weintraub, N. L. $\&$ Tang, C. Protective effects of ghrelin on ischemia/reperfusion injury in the isolated rat heart. J. Cardiovasc. Pharmacol., 43(2):165-70, 2004.

Communal, C.; Sumandea, M.; de Tombe, P.; Narula, J.; Solaro, R. J. \& Hajjar, R. J. Functional consequences of caspase activation in cardiac myocytes. Proc. Natl. Acad. Sci. U. S. A., 99(9):6252-6, 2002.

de Bold, A. J.; Borenstein, H. B.; Veress, A. T. \& Sonnenberg, H. A rapid and potent natriuretic response to intravenous injection of atrial myocardial extract in rats. Life Sci., 28(1):89-94, 1981.

de Bold, A. J.; Borenstein, H. B.; Veress, A. T. \& Sonnenberg, H. A rapid and potent natriuretic response to intravenous injection of atrial myocardial extract in rats. Reprinted from Life Sci. 28:89-94, 1981. J. Am. Soc. Nephrol., 12(2):403-9, 2001.

Ding, S.; Yang, Y. \& Mei, J. Protective Effects of L-malate against myocardial ischemia/reperfusion injury in rats. Evid. Based Complement. Altern. Med., 2016:3803657, 2016.

Dixit, V. D.; Schaffer, E. M.; Pyle, R. S.; Collins, G. D.; Sakthivel, S. K.; Palaniappan, R.; Lillard, J. W. Jr. \& Taub, D. D. Ghrelin inhibits leptinand activation-induced proinflammatory cytokine expression by human monocytes and T cells. J. Clin. Invest., 114(1):57-66, 2004.

Dogan, I.; Sezen, O.; Sonmez, B.; Zengin, A. Y.; Yenilmez, E.; Yulug, E.; Abidin, I. \& Bahat, Z. Myocardial perfusion alterations observed months after radiotherapy are related to the cellular damage. Nuklearmedizin, 49(6):209-15, 2010.

Dröge, W. Free radicals in the physiological control of cell function. Physiol. Rev., 82(1):47-95, 2002.

Eid, R. A.; Alkhateeb, M. A.; Al-Shraim, M.; Eleawa, S. M.; Shatoor, A. S.; El-Kott, A. F.; Zaki, M. S. A.; Shatoor, K. A.; Bin-Jaliah, I. \& AlHashem, F. H. Ghrelin prevents cardiac cell apoptosis during cardiac remodelling post experimentally induced myocardial infarction in rats via activation of Raf-MEK1/2-ERK1/2 signalling. Arch. Physiol.
Biochem., 1-11, 2018. [Epub ahead of print]

El-Gohary, O. A. \& Allam, M. M. Effect of vitamin D on isoprenalineinduced myocardial infarction in rats: possible role of peroxisome proliferator-activated receptor-g. Can. J. Physiol. Pharmacol., 95(6):641-6, 2017.

Finkel, T. Signal transduction by reactive oxygen species in non-phagocytic cells. J. Leukoc. Biol., 65(3):337-40, 1999.

Forssmann, W. G.; Birr, C.; Carlquist, M.; Christmann, M.; Finke, R.; Henschen, A.; Hock, D.; Kirchheim, H.; Kreye, V.; Lottspeich, F.; Metz, J.; Mutt, J. \& Reincke, M. The auricular myocardiocytes of the heart constitute an endocrine organ. Characterization of a porcine cardiac peptide hormone, cardiodilatin-126. Cell Tissue Res., 238(3):425-30, 1984

Frascarelli, S.; Ghelardoni, S.; Ronca-Testoni, S. \& Zucchi, R. Effect of ghrelin and synthetic growth hormone secretagogues in normal and ischemic rat heart. Basic Res. Cardiol., 98(6):401-5, 2003.

Gama, E. F. \& Rodrigues de Souza, R. Atrial natriuretic peptide (ANP)granules: ultrastructure, morphometry and function. Afr. J. Biotechnol., $5(25): 2534-9,2006$.

Gerbes, A. L.; Nathrath, W.; Cantin, M. \& Denecke, H. Presence of atrial natriuretic factor prohormone in enterochromaffin cells of the human large intestine. Gastroenterology, 101(2):424-9, 1991.

Gower, W. R. Jr.; McCuen, R. W.; Arimura, A.; Coy, D. A.; Dietz, J. R.; Landon, C. S. \& Schubert, M. L. Reciprocal paracrine pathways link atrial natriuretic peptide and somatostatin secretion in the antrum of the stomach. Regul. Pept., 110(2):101-6, 2003.

Gower, W. R. Jr.; Salhab, K. F.; Foulis, W. L.; Pillai, N.; Bundy, J. R.; Vesely, D. L.; Fabri, P. J. \& Dietz, J. R. Regulation of atrial natriuretic peptide gene expression in gastric antrum by fasting. Am. J. Physiol. Regul. Integr. Comp. Physiol., 278(3):R770-80, 2000.

Gutstein, D. E.; Liu, F Y..; Meyers, M. B.; Choo, A. \& Fishman, G. I. The organization of adherens junctions and desmosomes at the cardiac intercalated disc is independent of gap junctions. J. Cell Sci., 116(Pt. 5):875-85, 2003.

Hearse, D. J. Myocardial protection during ischemia and reperfusion. Mol. Cell. Biochem., 186(1-2):177-84, 1998.

Hirose, M.; Furukawa, Y.; Kurogouchi, F.; Nakajima, K.; Miyashita, K. \& Chiba, S. C-type natriuretic peptide increases myocardial contractility and sinus rate mediated by guanylyl cyclase-linked natriuretic peptide receptors in isolated, blood-perfused dog heart preparations. $J$. Pharmacol. Exp. Ther, 286(1):70-6, 1998.

Huang, C. X.; Yuan, M. J.; Huang, H.; Wu, G.; Liu, Y.; Yu, S. B.; Li, H. T. \& Wang, T. Ghrelin inhibits post-infarct myocardial remodeling and improves cardiac function through anti-inflammation effect. Peptides, 30(12):2286-91, 2009.

James, T. N. Normal and abnormal consequences of apoptosis in the human heart. From postnatal morphogenesis to paroxysmal arrhythmias. Circulation, 90(1):556-73, 1994

Jelonek, K.; Walaszczyk, A.; Gabrys, D.; Pietrowska, M.; Kanthou, C. \& Widak, P. Cardiac endothelial cells isolated from mouse heart - a novel model for radiobiology. Acta Biochim. Pol., 58(3):397-404, 2011.

Jiao, J. H.; Guyenet, P. G. \& Baertschi, A. L. Lower brain stem controls cardiac ANF secretion. Am. J. Physiol., 263:H198-207, 1993.

Kisch, B. Electron microscopy of the atrium of the heart. I. Guinea pig. Exp. Med. Surg., 14(2-3):99-112, 1956.

Knieriem, H. J. The significance of the "idiopathic" degeneration of the conduction system. Med. Klin., 73(3):75-83, 1978.

Lai, F. J.; Hsieh, M. C.; Hsin, S. C.; Lin, S. R.; Guh, J. Y.; Chen, H. C. \& Shin, S. J. The cellular localization of increased atrial natriuretic peptide mRNA and immunoreactivity in diabetic rat kidneys. J. Histochem. Cytochem., 50(11):1501-8, 2002.

Lesnefsky, E.; Chen, Q. \& Hoppel, C. L. Mitochondrial metabolism in aging heart. Circ. Res., 118(10):1593-611, 2016. 
EID, R. A.; ZAKI, M. S. A.; ALGHAMDI, M. A.; AL-SHRAIM, M.; EL-KOTT, A. F.; AL-HASHEM, F. H.; ALDERA, H. \& ALKHATEEB, M. A. Ghrelin improves the fine structure of atrial natriuretic factor (ANF) granules and intercalated disc junctions in experimentally-induced myocardial infarction in rats. Int. J. Morphol., 36(3):1031-1042, 2018.

Mifune, H.; Suzuki, S.; Noda, Y.; Hayashi, Y. \& Mochizuki, K. Fine structure of atrial natriuretic peptide (ANP)-granules in the atrial cardiocytes in the hamster, guinea pig, rabbit, cat and dog. Jikken Dobutsu, 41(3):3218, 1992.

Mifune, H.; Suzuki, S.; Noda, Y.; Mohri, S. \& Mochizuki, K. Fine structure of atrial natriuretic peptide(ANP)-granules in the atrial cardiocytes in the pig, cattle and horse. J. Vet. Med. Sci., 53(4):561-8, 1991.

Mifune, H.; Suzuki, S.; Nokihara, K. \& Noda, Y. Distribution of immunoreactive atrial and brain natriuretic peptides in the heart of the chicken, quail, snake and frog. Exp. Anim., 45(2):125-33, 1996.

Nagaya, N.; Kojima, M.; Uematsu, M.; Yamagishi, M.; Hosoda, H.; Oya, H.; Hayashi, Y. \& Kangawa, K. Hemodynamic and hormonal effects of human ghrelin in healthy volunteers. Am. J. Physiol. Regul. Integr. Comp. Physiol., 280(5):R1483-7, 2001a

Nagaya, N.; Miyatake, K.; Uematsu, M.; Oya, H.; Shimizu, W.; Hosoda, H.; Kojima, M.; Nakanishi, N.; Mori, H. \& Kangawa, K. Hemodynamic, renal, and hormonal effects of ghrelin infusion in patients with chronic heart failure. J. Clin. Endocrinol. Metab., 86(12):5854-9, 2001c.

Nagaya, N.; Moriya, J.; Yasumura, Y.; Uematsu, M.; Ono, F.; Shimizu, W.; Ueno, K.; Kitakaze, M.; Miyatake, K. \& Kanagawa, K. Effects of ghrelin administration on left ventricular function, exercise capacity, and muscle wasting in patients with chronic heart failure. Circulation, 110(24):36749, 2004.

Nagaya, N.; Uematsu, M.; Kojima, M.; Ikeda, Y.; Yoshihara, F.; Shimizu, W.; Hosoda, H.; Hirota, Y.; Ishida, H.; Mori, H. \& Kangawa, K. Chronic administration of ghrelin improves left ventricular dysfunction and attenuates development of cardiac cachexia in rats with heart failure. Circulation, 104(12):1430-5, $2001 \mathrm{~b}$.

Narula, J.; Pandey, P.; Arbustini, E.; Haider, N.; Narula, N.; Kolodgie, F. D.; Dal Bello, B.; Semigran, M. J.; Bielsa-Masdeu, A.; Dec, G. W.; Israels, S.; Ballester, M.; Virmani, R.; Saxena, S. \& Kharbanda, S. Apoptosis in heart failure: release of cytochrome $\mathrm{c}$ from mitochondria and activation of caspase-3 in human cardiomyopathy. Proc. Natl. Acad. Sci. U. S. A., 96(14):8144-9, 1999

National Research Council. Guide for the Care and Use of Laboratory Animals. Washington D. C., National Academy Press, 1996. pp.1-7.

Peng, N.; Chambless, B. D.; Oparil, S. \& Wyss, J. M. Alpha2A-adrenergic receptors mediate sympathoinhibitory responses to atrial natriuretic peptide in the mouse anterior hypothalamic nucleus. Hypertension, 41(3):571-5, 2003.

Perennec, J.; Herreman, F.; Cosma, H.; Ilers, F.; Djigouadi, Z.; Degeorges, M. \& Hatt, P. Y. Relationship of myocardial morphometry in aortic valve regurgitation to myocardial function and post-operative results. Basic Res. Cardiol., 83(1):10-23, 1988.

Rampazzo, A.; Calore, M.; van Hengel, J. \& van Roy, F. Intercalated discs and arrhythmogenic cardiomyopathy. Circ. Cardiovasc. Genet, 7(6):930-40, 2014.

Rocha, N. N.; de Oliveira, M. V.; Braga, C. L.; Guimarães, G.; Maia, L. A.; Padilha, G. A.; Silva, J. D.; Takiya, C. M.; Capelozzi, V. L.; Silva, P. L. \& Rocco, P. R. M. Ghrelin therapy improves lung and cardiovascular function in experimental emphysema. Respir. Res., 18(1):185, 2017.

Ryter, S. W.; Kim, H. P.; Hoetzel, A.; Park, J. W.; Nakahira, K.; Wang, X. \& Choi, A. M. Mechanisms of cell death in oxidative stress. Antioxid. Redox Signal, 9(1):49-89, 2007.

Severs, N. J.; Gourdie, R. G., Harfst, E.; Peters, N. S. \& Green, C. R. Intercellular junctions and the application of microscopical techniques: the cardiac gap junction as a case model. J. Microsc., 169(Pt. 3):299328, 1993.

Sheikh, F.; Chen, Y.; Liang, X.; Hirschy, A.; Stenbit, A. E.; Gu, Y.; Dalton, N. D.; Yajima, T.; Lu, Y.; Knowlton, K. U.; Peterson, K. L.; Perriard, J. C. \& Chen, J. alpha-E-catenin inactivation disrupts the cardiomyocyte adherens junction, resulting in cardiomyopathy and susceptibility to wall rupture. Circulation, 114(10):1046-55, 2006.

Skepper, J. N. \& Navaratnam, V. Analysis of the apparent heterogeneity of specific heart granules in rat atrial myocytes; an ultrastructural study including immunocytochemistry. Histochem. J., 20(1):1-10, 1988.
Soeki, T.; Kishimoto, I.; Schwenke, D. O.; Tokudome, T.; Horio, T.; Yoshida, M.; Hosoda, H. \& Kangawa, K. Ghrelin suppresses cardiac sympathetic activity and prevents early left ventricular remodeling in rats with myocardial infarction. Am. J. Physiol. Heart Circ. Physiol., 294(1):H426-32, 2008

Sorescu, D. \& Griendling, K. K. Reactive oxygen species, mitochondria, and $\mathrm{NAD}(\mathrm{P}) \mathrm{H}$ oxidases in the development and progression of heart failure. Congest. Heart Fail., 8(3):132-40, 2002.

Veress, A. T. \& Sonnenberg, H. Right atrial appendectomy reduces the renal response to acute hypervolemia in the rat. Am. J. Physiol., 247(3 Pt. 2):R610-3, 1984.

Wang, J.; Boerma, M.; Fu, Q. \& Hauer-Jensen, M. Significance of endothelial dysfunction in the pathogenesis of early and delayed radiation enteropathy. World J. Gastroenterol., 13(22):3047-55, 2007.

Wyllie, A. H. Apoptosis: cell death in tissue regulation. J. Pathol., 153(4):313-6, 1987

Yoshihara, F.; Nashikimi, T.; Kosakai, Y.; Isobe, F.; Matsuoka, H.; Takishita, S.; Kawashima, Y.; Saito, Y.; Matsuo, H. \& Kangawa, K. Atrial natriuretic peptide secretion and body fluid balance after bilateral atrial appendectomy by the maze procedure. J. Thorac. Cardiovasc. Surg., $116(2): 213-9,1998$

Zankov, D. P.; Shimizu, A.; Tanaka-Okamoto, M.; Miyoshi, J. \& Ogita, H. Protective effects of intercalated disk protein afadin on chronic pressure overload-induced myocardial damage. Sci. Rep., 7:39335, 2017.

Zhang, Q.; Moalem, J.; Tse, J.; Scholz, P. M. \& Weiss, H. R. Effects of natriuretic peptides on ventricular myocyte contraction and role of cyclic GMP signaling. Eur. J. Pharmacol., 510(3):209-15, 2005.

Zhang, Y. \& Yang, Y. Arctigenin exerts protective effects against myocardial infarction via regulation of iNOS, COX-2, ERK1/2 and HO-1 in rats. Mol. Med. Rep., 17(3):4839-45, 2018.

Zhao, L.; Mason, N. A.; Strange, J. W.; Walker, H. \& Wilkins, M. R. Beneficial effects of phosphodiesterase 5 inhibition in pulmonary hypertension are influenced by natriuretic Peptide activity. Circulation, 107(2):234-7, 2003.

Corresponding author:

Dr. Refaat Ali Mohammed Eid, Ph.D.

Department of Pathology

College of Medicine

King Khalid University

Abha

SAUDIARABIA

Email: refaat_eid@yahoo.com

Received: 03-03-2018

Accepted: 07-05-2018 